\title{
Remembering War: Fabre on Remembrance ${ }^{1}$
}

\author{
Zofia Stemplowska
}

Throughout the war, in the Warsaw Ghetto, the imprisoned historian Emanuel Ringelblum and his team assembled papers that would document Jewish life during the war and before. As he was helping to hide the archive from the Germans who were wiping out the Warsaw Ghetto, Israel Lichtenstein added a document in which he wrote

'I only wish to be remembered.... I wish my wife to be remembered, Gele Sekstein. She has worked during the war years with children as an educator and teacher, has prepared stage sets, costumes for the children's theatre...both of us get ready to meet and receive death.

I wish my little daughter to be remembered. Margalit is 20 months old today. She has fully mastered the Yiddish language and speaks it perfectly. At nine months she begun to speak Yiddish clearly. In intelligence she equals children of 3 or 4 years. I don't boast. People who witness it and tell me so are the staff teaching at the school at 68 Nowolipki Street - Dr. Pola Follman, Mrs. Blit Herzlich, Mrs. Zagan and others. I don’t lament my own life or that of my wife. I pity only this little nice and talented girl. She too deserves to be remembered.'2

A teenager who was there, 18 year old Nahum Grzywacz, added on a scrap of paper his own call, finishing:

'I am going to run to my parents and see if they are all right. I don’t know what's going to happen to me. Remember, my name is Nahum Grzywacz. ${ }^{3}$

So remembrance matters to the victims of war. It matters so greatly that, as Cécile Fabre points out, the Imperial War Museum was established well before the First World War came to an end. ${ }^{4}$

But what obligations, if any, of remembrance do we - those who live in peacetime - have? On whom do they fall? Who must be remembered? How should they be remembered? Fabre offers us an 
account of remembrance that answers some of those questions and provides a helpful framework for working through the others. It is philosophically nuanced as well as attuned to the complexity of war and informed by actual commemorative practices. I will outline the account below but my focus in this short paper will be on expanding Fabre's list of desiderata that a good account of war remembrance must meet. I will argue that Fabre's account needs to be refined and, at least in one respect, revised in light of these new desiderata. In the final section I will sketch such a revision, which relies on an appeal to a 'moral debt' created by wrongdoing. Whether it is possible to construct an account of remembrance that could meet all the desiderata I put forward below will have to be left for another occasion.

For reasons of space, I will not comment here on which actions and practices might qualify as remembering. Also like Fabre, I will use 'commemoration' without implying that what is commemorated (e.g. war, crime, atrocity, death, etc.) is valuable, even if there is value in commemorating it or some features of it or relating to it. My focus, as Fabre's, is on the commemoration of war (understood broadly to include killing through deliberate famines, class cleansing, pogroms and genocide) but I do not mean to suggest, thereby, that war is special over and above the scale of the wrongdoing and harm it involves.

One final clarification: I will use the word 'victims' to refer not only to civilians but also soldiers who were wronged through war. Unless I qualify my usage I mean the term victim to denote victims who are not also blameworthy perpetrators.

\section{Fabre's account}

In Cosmopolitan Peace Fabre argues that there are moral requirements to remember war. She grounds the requirements in the instrumental and inherent value of remembrance. The inherent value of remembrance resides, for Fabre, in the fact that remembrance of victims of war is a way of recognizing their value as humans (a value that itself grounds the duty to promote just peace that is relevant to the rest of Fabre's account). ${ }^{5}$ It is because people are valuable, argues Fabre, that we need to attend 'to the plight of those who suffer from and through war'. We have 'a reason to ensure as 
much as we can that they are not forgotten'. ${ }^{6}$ In fact, we must do it publically or else we fail 'to acknowledge the seriousness of the wrongdoings to which they were subject' and so fail in 'respect'. ${ }^{7}$ One implication here, according to Fabre, is that we should remember the victims by name if we can, in order to acknowledge each person's unique and specific value.

The need to respond to the inherent value of remembrance may be enough to ground requirements to remember, but Fabre's account is clearest on how the instrumental value of remembrance grounds such requirements. ${ }^{8}$ The focus on instrumental value also helps to point individuals and communities towards specific acts of remembrance out of the many they could engage in. Specifically, Fabre emphasises that communal remembrance - that is, remembrance engaged in by specific communities, for example nation-states - and universal remembrance - that is, remembrance engaged in by individuals qua humans rather than members of specific communities - can serve not only the affirmation of the value of human life but also the promotion of just peace.

The requirement of universal remembrance, argues Fabre, arises for wars of universal human significance such as, for example, the world wars and genocide. As Fabre puts it, ' $[\mathrm{t}$ o the question "will our successors have strong moral reasons to remember the Holocaust two hundred years from now?”, the answer might well be 'yes', if remembering the Holocaust is one way to affirm rejection of its evilness and to minimize the risk that they will allow yet another genocide to be carried out.' ${ }^{9}$

Communal remembrance can also be instrumentally valuable. This is because, argues Fabre, the right type of remembrance can foster (inclusive) political relationships that are conducive to peace. ${ }^{10}$ Although it seems that communal remembrance could play a direct role here - the remembrance of suffering, for example, could directly strengthen each person's commitment to just peace - Fabre emphasizes its indirect role: communal remembrance (of the right type) strengthens the (right type of) communal bonds and these bonds in turn help us avoid participating in wars. ${ }^{11}$

The role that remembrance is meant to play obviously has implications for the forms that remembrance should take. Fabre suggests, for example, that partial remembrance is not of the right kind. For instance, she is critical of a UK First World War 2014 commemoration event that involved a 
collection of ceramic red poppies that were meant to represent only the British military fatalities. Such remembrance was 'at odds with cosmopolitan remembrance'. ${ }^{12}$ She also argues that the perpetrators themselves should, once enough time has elapsed, be remembered with sadness or regret. I will look at both suggestions below. For now my point is only that whether a form of remembrance is admissible or not is meant to depend on whether it serves the instrumental role of promoting cosmopolitan peace. More generally, as I interpret Fabre’s instrumental feature of remembrance is that it both sets limits on acceptable remembrance of what is inherently valuable and explains which inherently valuable forms of remembrance ought to be pursued (given limited resources for remembrance and so many victims to remember).

What criteria bear on whether we have identified the right account of remembrance (beyond, obviously, whether the account can do what it says it can)? Fabre highlights three desiderata for an account of appropriate war remembrance:

(1) It asks that we commemorate only some features of the war and does not make us celebrate pointless harm and loss.

(2) It allows remembrance to strengthen only the right type of communal bonds - e.g. it does not nurture groups such as the KKK or neo-Nazis.

(3) It offers grounds for communal remembrance even to historically and culturally diverse communities.

How does Fabre's account meet these three desiderata? Take communal remembrance that's oriented towards just peace. Such remembrance is likely to meet the first desideratum since it is unlikely that celebration of pointless harm and loss would be conducive to just peace, while it is likely that the remembrance of all the victims of war (e.g. not just those on 'our side') would be. Moreover, because it is focused on the promotion of just peace, such remembrance would be unlikely to strengthen the bonds of unjustifiably violent or racist communities, thus meeting the second desideratum. And, in line with desideratum three, even recent immigrants into a given community would have reasons to participate in remembrance oriented towards peace. 
Are the desiderata themselves correct? The first two seem most clearly so. Notice that desideratum (1) might be thought of as internal to remembrance: it identifies the object of remembrance. Desideratum (2) can be thought of as external: it makes sure that remembrance does not have consequences that make it unacceptable in light of our broader commitments (some of which are about preventing future war). Fabre’s account thus can also be seen as meeting a further desirable external desideratum (4): remembrance does not derail and even promotes just peace. I am less certain that a good account of remembrance must meet desideratum (3) and offer grounds for communal remembrance even to recent immigrants into specific communities, but I am prepared to accept it as a bonus if it does.

In what follows, however, I will argue that a good account of remembrance should meet further desiderata, some of which are as important as the three - or four - mentioned above. I do not offer a comprehensive list, ${ }^{13}$ but a list drawn up in response to features of Fabre's own account.

\section{What do we want from an account of remembrance?}

\subsection{What should be remembered?}

What are we to commemorate? In an evocative passage Fabre answers this question:

'Appropriately commemorating war does not simply consist in openly marking its beginning and its end: it also requires that we should commemorate individual actors who typically suffered in it: the combatants who fought and killed; those who refused to fight and were punished with death; those who lost control of their bowels while going over the top and fell screaming in agony; civilians who were subject to the horrors of gang rape, torture, and summary execution by occupying and/or allegedly liberating combatants; those who collaborated with those combatants and were complicitous in the latter's wrongdoings out of greed, ideological commitment, or the simple need to survive; those who lost loved ones to its horrors.' 
The focus of the passage is on commemorating suffering. Similarly, when Fabre explains that her account is victim-centered, she emphasises the importance of commemorating the victims' suffering and the wrongs perpetrated against them. ${ }^{14}$

But I think the focus of our commemoration, when we commemorate the victims, should lie elsewhere: on the lives of the victims. Remembering the whole lives, rather than simply the suffering, death and wrongs, means commemorating the preferences, concerns, projects, relationships and forms of acting and being of the victims. To be clear, how people died and what was done to them forms part of their lives but only a part.

There are multiple reasons in defence of this shift in commemorative focus. First, many victims wanted us to remember not only the wrongs done against them but the lives they have lived. Israel Lichtenstein wanted us to remember his daughter's intelligence and her way with words. Gele Sekstein, his wife, wanted us to remember her family background. ${ }^{15}$ Responding to their otherwise morally permissible wishes can be seen as respecting the victims. Second, remembering lives often means paying attention to the concerns and projects that people had. This can translate into us supporting some of these projects. I argue elsewhere that advancing (otherwise morally acceptable) projects of victims mitigates some of the injustice they suffered. Focusing our remembrance on lives can thus indirectly help mitigate some of the injustice. ${ }^{16}$ Third, commemorating the lives of the victims more effectively allows us to limit the power of the perpetrators who set out to destroy those lives. Remembering the lives of the victims curtails, even if in a miniscule way, some of the destruction perpetrators brought to bear on the victims. ${ }^{17}$ Fourth, remembering the lives - appreciating the detail of those lives - is essential to the recognition of the scale of the wrongdoing.

This suggestion for a shift in focus of remembrance is not meant to compete with Fabre's requirement to commemorate the suffering but rather to complement it. This translates into the following requirement: 
(5) A good account of remembrances should permit (and likely require) that we focus our remembrances on the lives of the victims rather than primarily the suffering and the horrors of the war. $^{18}$

\subsection{How should we remember?}

The sheer technical challenge of remembrance is enormous given the numbers of war victims involved. In addition, if we think that war is not special, over and above the scale of the wrongdoing and harm it involves, as I suggested above, then our requirements to remember will likely include countless victims of all sorts of injustice. ${ }^{19}$ This means developing criteria for selective remembrance. But there is a distinct question about the appropriate emotional states of those doing the commemorating I want to focus on. Fabre answers by saying that we should remember those involved with sorrow. ${ }^{20}$ The 'dominant emotion' we are meant to experience is 'sadness' or 'regret'. ${ }^{21}$ This prescription is meant to encompass remembering the wrongdoers. Even the wrongdoers - even those 'deeply committed to what they were doing', even 'the committed members of...Einsatzgruppen' should be remembered, if not with sadness (though this is appropriate) then with regret. As Fabre puts it, ' ...there comes a time when the perception that one’s ancestors were wronged by the enemy and (conversely) when the recognition that our ancestors did wrong, must give way to profound regret at what was done (as distinct from anger for what they did to us and guilt at what we did to them). ${ }^{22}$ The assumption in the background, I think, is that the commemoration is not done by the victims themselves. I do not think that Fabre is committed to the thought that victims must feel sadness or regret in commemorating the wrongdoers (she may be suggesting that the descendants of the victims should, but I will put this aside). But even then, it is not obvious to me that the dominant emotions felt by third parties in commemoration of the perpetrators must be sadness or regret. To be clear, I do not wish to challenge here the thought that certain emotional states may be more or less apt. My objection concerns instead the prescribed content of the emotional states.

Fabre may be advocating sadness or regret as the dominant emotions in remembering wrongdoers in order to take account of the fact that many wrongdoers - perhaps almost all - were also victims of 
war. But I think we could (and should) recognize this fact without accepting the prescription. A good account of remembrance should allow our emotional states to track the complexity of the apt moral judgements we must make about what took place. The emotions involved in remembering perpetrators could be, for example, anger at what they have done and what was done to them. But it could also simply be relief that they are gone. I would thus add the following desideratum:

(6) A good account of remembrance should let us remember the perpetrators without sadness or regret.

\subsection{Who should be remembered?}

Must the perpetrators - at least those whom we should not see as victims - be remembered at all? Of course, to learn from history we need a record of their existence. To learn from history, we also need to be able to remember that apparently average people are prepared, and even eager, to participate in extraordinary evil. ${ }^{23}$ But this does not mean that we have to remember specific wrongdoers by name or image. Suppose, for example, that when we display their photos in war museums we choose those that show them from behind. ${ }^{24}$ Suppose even that we simply forget their names (though we could consult the record to learn them) and do not think about them at all or, when we do, purely instrumentally - to highlight the things done to the victims or to make sure we learn about the conditions that elicit evil. This does not strike me as an excessive reaction to wrongdoing of sufficient magnitude.

What about our remembrance of the victims? Fabre's account can be read as suggesting that remembrance that focuses exclusively on our 'own' victims is incompatible with cosmopolitan ideas. We can readily understand the thought behind it: some forms of partial remembrance at least imply that those not commemorated are not worth remembering. Thus were Britain to mention exclusively Allied victims of the Second World War at a commemoration ceremony this could reasonably be read as implying that none of the Germans were victims worthy of commemoration. Such a commemoration may well unsettle the processes that sustain peace rather than help strengthen them. 
That said, not all forms of partial remembrance seem inappropriate. Presumably, a University would be morally justified in commemorating only the victims who were its members, by having only their names read out at a ceremony. What seems to matter here is that the partiality of the remembrance does not track the lines of conflict that fuelled the war. As a result, normally, there is no implication that the victims who did not belong to the University were not really victims, or are not worthy of commemoration. We can thus add a further desideratum:

(7) A good account of remembrance should be compatible with us not commemorating the perpetrators and should permit partial remembrance of victims iff it does not imply that some victims of the same war are unworthy of commemoration. ${ }^{25}$

\subsection{Who should commemorate?}

Fabre's account seems compatible with a situation in which a given community remembers the wars of universal significance and commemorates those it was a victim or a hero of, but does not commemorate (and even for the most part forgets) the wars in which it was an unjust side. I will sketch a justification for the requirement to commemorate the victims of one's own wrongdoing in the final section. For now, I will take it as given that a good account of remembrance should rule out such selective remembrance.

As a phenomenon, selective remembrance is not unusual. Britain, for example, does not seem to go out of its way to commemorate the massacres of its colonial rule. Given its imperial past, there is a lot that Britain in particular is forgetting to commemorate, but practically all war-waging states are guilty of some public forgetting. ${ }^{26}$ Fabre herself is worried by the phenomenon and criticises the Vietnam Veterans Memorial in Washington for not mentioning any of the Vietnamese victims. ${ }^{27}$

Fabre might respond that she can avoid sanctioning such non-remembrance even when it comes to wars that are not of universal significance. How? We need a 'division of labour’ whereby different groups remember different wars. Since each community would find it relatively easier to remember wars that resulted in its own members suffering, we should expect such communities to commemorate the relevant wars. ${ }^{28}$ And if we then couple this idea with the requirement mentioned above regarding 
the absence of objectionably partial remembrance (that implies the victims on the other side are not worthy of commemoration) we will end up with the right commemorative picture overall, in which each state commemorates all its own (not too distant) wars.

But I do not think this will work. Nation-states would sometimes rather forgo commemorating their own victims than remember those they wronged and harmed.

Fabre might respond that such public forgetting would be blocked by the requirement to commemorate when this is conducive to just peace: forgetting to remember the suffering one can cause may feed into a dangerous narrative, in which a given nation is always a victim and the world has nothing to fear from its own power. I think this line of reasoning can take us some way towards the requirement for states to commemorate those they harmed, but not to the ultimate destination. This is because a state could commemorate just a fraction of its wrongdoing and thereby achieve the instrumental benefits of commemoration.

But it seems intuitive that communities that wronged others have special reason to remember the wrongdoing and remember themselves as the wrongdoers:

(8) A good account of remembrance should explain why communities should commemorate all the not too distant wars they were involved in as wrongdoers.

\section{A requirement to remember: A Fabre-esque account}

What I offered above is not a complete set of desiderata, but it takes us some way towards what I would consider to be a good account. This leaves me with next to no space to discuss the content of such an account. But let me sketch one feature of it. I will put aside the problem of what grounds the requirement to commemorate the victims of war who become victims due to no fault of the state to which the commemorators belong. I think that a combination of victim-centered and instrumental considerations, as Fabre suggests, get us the right answer here. I want to ask instead how to ground the requirement to commemorate the victims for whose plight the state of the commemorators is 
responsible (while leaving aside the broader question of how to fit any requirements here with the requirements grounded in other inherent value and instrumental considerations).

In a nutshell, my answer is as follows. A state that wages (unjust) war acquires a moral debt owed to its victims, individual and collective. A moral debt here is the debt we acquire over and above any material debts we do as a result of violating the rights of others. Commemorating the victims of one's wrongdoing helps the perpetrator to repay some of that moral debt.

There are clearly many controversial claims here. Does commemoration help to repay the moral debt? Can states acquire moral debts? Is it permissible that the state's duty to commemorate should translate into burdens for individuals from subsequent generations and the new arrivals? Fabre may think that at least one of those questions will get a negative answer, so we will need to fall back on her account that does not reference moral debts. As we do so, however, we should still try to refine it some other way to make sure that the account can meet the additional desiderata I suggested above.

Remembrance is a philosophically and morally urgent problem. If we don't direct the remembering in light of our ethical principles, chances are we will remember badly.

\footnotetext{
${ }^{1}$ I am grateful to the audiences at the Birmingham workshop on Cosmopolitan Peace, the Oxford Centre for the Study of Social Justice and at the Essex Politics seminar. I am especially grateful to Ben Jackson, Cécile Fabre, Tom Parr, Jonathan Parry and Jeremy Williams for written comments that led to significant revisions.

${ }^{2}$ Samuel D. Kassow, Who will write our history?, pp. 3-4.

${ }^{3}$ Kassow, Who will write..., p. 4.

${ }^{4}$ It was established in 1917. Cécile Fabre, Cosmopolitan Peace, Oxford University Press, 2016, p. 284, n. 5.

[All references to Fabre below, unless otherwise specified, are to this book.]

${ }^{5}$ Since Fabre does not believe in owing things to the dead, the value is impersonal and/or concerns the living.

${ }^{6}$ Fabre, 296.

${ }^{7}$ Fabre, 296.

${ }^{8}$ The two could come in conflict and if they do I assume Fabre would privilege the instrumental value (given the importance of what it is an instrument for).
} 


\footnotetext{
${ }^{9}$ Fabre, 301.

${ }^{10}$ Fabre, 297.

${ }^{11}$ Fabre 296.

12 Fabre 299.
}

${ }^{13}$ A fuller list would include, inter alia, (A) a desideratum concerning the priority of remembrance of the more recent wars over the more temporally distant ones when holding their severity constant, (B) a desideratum to remember wars (and injustice more broadly) in in proportion to their severity/impact on the victims, (C) a desideratum regarding how to incorporate the victim’s wishes concerning remembrance, and (D) a desideratum regarding how long the victims need to be remembered for and by how many (and how to trade off these when they are in conflict).

14 Fabre, 297.

${ }^{15}$ Kassow, Who will write..., p. 4.

${ }^{16}$ Zofia Stemplowska, ‘The Descendants: Changing Identity to Rectify Injustice’, working paper. Because in her other works Fabre argues that the deceased can't have surviving interests, she would need to ground differently this conclusion than I do. Cf. Fabre, 'Posthumous Rights’ in M. Kramer, C. Grant, B. Colburn, and A. Hatzistavrou (eds.) The Legacy of H. L. A. Hart, OUP, 2008.

${ }^{17}$ I say more about this in Zofia Stemplowska, 'Should coercive neurointerventions target the victims of wrongdoing?', in David Birks and Tom Douglas (eds.), Treatment for Crime, OUP, forthcoming 2018. See also Daniel Butt, Rectifying International Injustice, pp. 129-130; Bashshar Haydar and Gerhard Øverland, ‘The Normative Implications of Benefiting from Injustice’, Journal of Applied Philosophy, 31 (2014), 349-62, p. 356; Tom Parr, 'On the Moral Taintedness of Benefiting from Injustice’, Ethical Theory and Moral Practice, 19 (2016), 985-99; Zofia Stemplowska, 'Should coercive neurointerventions target the victims of wrongdoing?', forthcoming in David Birks and Tom Douglas (eds.), Treatment for Crime, OUP, 2017.

${ }^{18}$ A full account would need to offer further conditions that deal with commemoration of things other than victimhood, for example, heroism. It will matter also how an account allows us to understand a given war: a waste of life and/or an opportunity to show heroism, etc. I am grateful to an Associate Editor for this point. ${ }^{19}$ Moreover, if it turns out that remembering war makes us more rather than less bloodthirsty, an account of remembrance of war that is oriented towards peace may, in fact, prioritise our remembrance of victims of things other than war. This may be problematic for the account as an account of remembrance of war, though it may be 
the right result regarding where to direct our remembrance. I am grateful to an anonymous reviewer for making me clarify this.

${ }^{20}$ Fabre, 301.

${ }^{21}$ Fabre, 302.

${ }^{22}$ Fabre, 303.

${ }^{23}$ I am grateful to an Associate Editor for this point, including some of the phrasing of the sentence.

${ }^{24}$ As displayed, where an appropriate photo is available, in Polin: The Museum of the History of the Polish Jews, Warsaw. Zofia Stemplowska, 'Polin: A Wish to be Remembered’, Times Literary Supplement, 19 November 2014 (https://www.the-tls.co.uk/articles/public/polin-a-wish-to-be-remembered/).

${ }^{25}$ Victims who are also perpetrators could still be commemorated as victims.

${ }^{26}$ I do not meant to suggest that these particular wars and massacres might not qualify as universally significant only that there will be some wars that are forgotten that do not. Poland, for one, does not commemorate its taking of Zaolzie from Czechoslovakia in 1938. Even if the taking were ultimately sanctioned by Prague who had been cornered by the German annexation of Sudetenland, it is still striking that it is hardly ever publicly acknowledged in Polish commemorations. We can also witness cases of remembering of violence in which a given state did not play any major roles and which is not done out of humanitarian concerns. For example, the remembrance of US chattel slavery in the Soviet Union and its successor is promoted by the state at times not because of its universal significance but because of the fact that it allows for (justified) criticism of the US. ${ }^{27}$ Fabre, 291-2.

${ }^{28}$ Fabre draws here an explicit parallel with debates about global justice and the best instrumental division of duties: even if we are all under a duty to all it may still be instrumentally best if any given state ends up primarily responsible for the plight of its own members. 